spermatocytes of the grasshopper Attractomorpha sp., while meiosis and chiasma formation in another grasshopper, Tristria pulvinata, is the subject of a paper by M. K. Dutt. In a study of the seales in Glossogobuis giuris, S. Mookerjee shows that the ctenoid condition is an advance on the cycloid which occurs earlier in development. The bionomics and reproduction of another fish, Ophicephalus striatus, are discussed by H. K. Mookerjee, D. N. Ganguly and R. N. Bhattacharya, and R. P. Dhar contributes a hæmatological note on a closely allied species. Some myxosporidians parasitic in fishes are described by M. Chakravarty and S. P. Basu. Termite control with various insecticides tried out in the field is the subject of an investigation by D. Mukerji and P. K. Mitra, and the final paper, concerning the development of the vertebral column in Alligator mississippiensis, is by H. K. Mookerjee and R. N. Bhattacharya. Text and figures are clearly printed on good art papor. $5 / 6$

\section{Preslia: Botanical Research in Czechoslovakia}

The Czechoslovak Bamical Society has just published a comprehe Ive issue (vols. 22 and 23, pp. 248) of its ro Hangs, Preslia, for the years 1943-47. The perikdjez, named after the brothers J. S. and K. B. Fresl, who flourished in the first half of the lasp pentury, had been an annual publication for sop. time before the War, but nevertheless served as a repository for the results of botanical research in Czechoslovakia. The Society now has an active membership of more than two hundred, besides that of some twenty-nine (pre-war, thirty-seven) affiliated societies and naturalists' clubs. During the period under review it was mainly through these that botanists were able to continue working and publishing. The current issue of Preslia lists these contributions for the years 1939 to 1947 as well as describing (in English and Czech) the recent history of some of the affiliated institutions. Some institutes are still not in working order. Dr. I. Klašteršký is held up with his work on the genus Rosa; Prof. J. Peklo lacks facilities for his phytopathological studies, and Prof. K. Domin cannot obtain the foreign literature he needs for comparative purposes. So far as botany is concerned, Slovakia appears to have suffered less than Bohemia, though Prof. B Nømec states that the Bratislava University Institute for Plant Physiology lacks microscopes and other equipment, and is without a proper library. A note in Preslia refers to the failure of the Botanical Society to obtain a grant from Unesco through the Association Internationale des Microbiologistes, and this is likely to delay further publication. In 1938 a group of botanists founded a journal, Studia Botanica Cechosloraka. It survived until 1943, and hope is now expressed that it will resume publication under the erlito hip of Prof. S. Prát and Dr. I. Klašteršký. Toxicity ${ }^{2}$ Certain Synthetic Organic Compounds to Insects

THIs subject is ispynsed in the Canadian Journal of Research, June $1 \mathbf{4 8}$, in a paper divided into two parts. In Paf Do Messrs. A. W. A. Brown, D. B. W. Robinson, N: Hurtig and B. J. Werner record their resurp from testing the general toxicity of some 127 synth fre compounds when mixed in graded eoncentrations in the food of the larvæ of the housefly (Musca domestica), the confused flour beetle (Tribolium confusum), the Mediterranean flour moth (Ephestia Kuhniella) and adults of the granary weevil (Sitophilus granaria). Each compound was intimately mixed with the food medium in which each of the foregoing insects lives and feeds. The method of testing gives an overall measure of the contact, stomach, and fumigant action of each compound without distinction as to its mode of action. The most highly toxic substanees were found to be 'Gammexane' (the gamma isomer of hexachlorocyclohexane) and chlordane (obtained by the distillation of technical chlordane). The toxicity of D.D.T. was, on an average, one half of that of these two compounds. In Part 2 Messrs. A. W. A. Brown, B. J. Werner and F. E. Park record the results of their experiments regarding the direct toxicity of 91 compounds against the nymphs of the German cockroach (Blatella germanica) and of the large milk-weed bug (Oncopeltis fasciatus), continuously reared in the laboratory on seeds of Asclepias syriaca, and also adults of the confused flour beetle (Tribolium confusum). The compounds used were dissolved in graded concentrations in a benzinekerosene mixture and sprayed on the insects confined in a cylindrical glass spraying tower $29 \mathrm{in}$. high. Compressed air was applied to an atomizer at a uniform pressure of $23 \mathrm{~cm}$. mercury. Taking the results with the three species of insects as a whole, the highest contact toxicity was shown by 'Gammexane' and chlordane. Dinitro-o-cresol and dinitrocyclohexylphenol were next in order of effectiveness. The results described in the two parts of this paper are based on tests carried out at the Experimental Station, Suffield, Alberta.

\section{International Veterinary Congress}

The Fourteenth International Veterinary Congress will take place in London during August 8-13, 1949, and the meetings will be beld at the Central Hall, Westminster, and in Church House, Westminster, S.W.1. The Dake of Gloucester, who is the president of the Broyal Veterinary College and Hospital of London, hopes to be able to open the Congress. As it is considey that the present world food situation is the most important scientific and practical question of the day, the programme of the Congress has been based on this theme. Every morning there will be a plenary session at which a paper will be presented by a leading authority on the veterinary profession's contribution to some aspect of world food production. Sectional meetings will be held in the afternoons, and the programme for these is designed to cover a wide range of subjects. The executive committee has been appointed as follows : President, Sir Daniel Cabot; vice-president, Prof. J. B. Buxton ; honorary secretary, Dr. W. R. Wooldridge; honorary treasurer, Mr. G. N. Gould; general secretary, Mr. W. G. R. Oates. An exhibition of the latest instruments, appliances, drugs, disinfectants, books, ete., will be arranged near to the Central Hall. Social functions have been arranged for the evening of August 7, and during the week of August 15-20 excursions will be made to places and establishments of veterinary interest. Official invitations to the Congress have been issued by the Government of Great B.itain to foreign, Commonwealth and Colonial Governments. Representation has been invited not. only from government veterinary departments, but also from universities, veterinary schools and other interested bodies in every country. Persons desirous of attending the Congress should apply as early as possible, and all inquiries should be addressed to the Organising Secretary, Fourteenth International Veterinary Congress, 10 Red Lion Square, London, W.C.1. 